Journal of Engineering and Applied Sciences 14 (Special Issue 4): 7302-7304, 2019

ISSN: 1816-949X

(C) Medwell Journals, 2019

\title{
Metal Foam via. Recycling of Aluminum Aerosol Cans as a Raw Material and Dolomite as a Foaming Agent
}

\author{
Hayder Al-Juboori, Nabil Al-Saffar and Kararr Farhan \\ Department of Metallurgy Engineering, College of Materials Engineering, University of Babylon, \\ Hillah, Iraq eng.kararr.farhan@gmail.com
}

\begin{abstract}
Aluminum foams have been considered recently as one of the most promising popular materials. This due to their properties such as low density with high stiffness. Automobiles, railways, aerospace, shipbuilding, household applications and other, they all can use aluminum foams. Despite the unique features of aluminum foams but they still limited in using because of their expensive fabrication costs. However, this study introduced the recycling of aerosol aluminum cans to reduce the manufacturing cost of metallic foams with using dolomite as a foaming agent while it discussed the effects of the grain size for dolomite $\left(\mathrm{CaMg}\left(\mathrm{CO}_{3}\right)_{2}\right)$ on physical properties of the manufactured aluminum alloy. The foams were produced with a different grain size of dolomite $(90,125,150$ and $180 \mu \mathrm{m})$ as a foaming agent. Foam density and porosity resulted was calculated using (mass-volume direct method). Relative density resulted was in the range of $0.21-0.33$ with $10-23$ pores per inch for the produced $\mathrm{Al}$ alloy closed cell foam. While the energy absorbed by fabricated foams was in range $\left(0.5-0.42 \mathrm{MJ} / \mathrm{m}^{3}\right)$.
\end{abstract}

Key words: Cheap metal foam, dolomite, recycling aerosol aluminum cans, automobiles, fabrication, foaming agent

\section{INTRODUCTION}

"When modern man builds large load-bearing structures, he uses dense solids; steel, concrete, glass. When nature does the same, she generally uses cellular materials; wood, bone, coral. There must be a reason for it" (Ashby et al., 2000).

The last years recorded significantly interesting in cellular metals generally and closed-cell metallic foam especially, due to excellent properties like; low density, energy absorption, mechanical damping. Aluminum alloys are the common alloys which are exploiting to fabricate metal foam. Many foaming agents like; $\mathrm{TiH}_{2}$ (Miyoshi et al., 1998), $\mathrm{CaCO}_{3}$ (Curran, 2004) and recently dolomite (Papadopoulos et al., 2011) have been used to form bubbles in the metal foam. In the present research, dolomite and recycled aerosol aluminum cans were used to fabricated metal foam. However, the process which used to make the metallic foams in the present study was the Alporas modified process without using calcium for modifying the viscosity of the molten alloy where $\mathrm{MgO}$ and $\mathrm{CaO}$ which are resulting by the decomposition of dolomite act as a viscosity modifier to prevent bubbles escape through the foaming process. Alporas process parameters studied by many researchers where the most important foaming process parameters were foaming temperature, stirring mode and stirring time (Yang et al., 2007) and holding time (Song et al., 2001). However, the publications on the effect of foaming agent particle size are almost nonexistent. The particle sizes of dolomite which selected in the present research were $(90,125,150$, $180 \mu \mathrm{m})$ to determine their effect on the properties of the fabricated metal foam. On the other hand, many studies pointed to the toxic effects of aerosol aluminum cans (Krewski et al., 2007; Sorenson et al., 1974), so, they selected as the raw material for fabrication metal foam in this study. However, the use of dolomite as a foaming agent and aluminum cans is significantly reducing the production cost.

\section{MATERIALS AND METHODS}

Dolomite rocks with purity (99\%) used as a foaming agent, the rocks are milled and particle size analyzed to obtain the required particle sized $(90,125,150,180 \mu \mathrm{m})$. On the other hand, the raw material was the recycled aerosol aluminum cans. Figure 1 shows the stages of recycling the raw material (i.e., aerosol aluminum cans). While Table 1 show the chemical composition of recycled aluminum cans which used in fabrication metal foam.

Corresponding Author: Hayder Al-Juboori, Department of Metallurgy Engineering, College of Materials Engineering, University of Babylon, Hillah, Iraq, eng.kararr.farhan@gmail.com 
Table 1: The chemical composition of recycled aerosol aluminum cans

\begin{tabular}{lllllllllll}
$\mathrm{Si}(\%)$ & $\mathrm{Fe}(\%)$ & $\mathrm{Cu}(\%)$ & $\mathrm{Mn}$ & $\mathrm{Mg}(\%)$ & $\mathrm{Cr}(\%)$ & $\mathrm{Ni}(\%)$ & $\mathrm{Zn}(\%)$ & $\mathrm{Pb}$ & $\mathrm{Ti}$ & $\mathrm{Al}(\%)$ \\
\hline 0.122 & 0.261 & 0.0027 & 0.0098 & 0.0028 & 0.0017 & 0.0013 & 0.0063 & 0.0005 & 0.0181 & $\mathrm{Bal}$
\end{tabular}

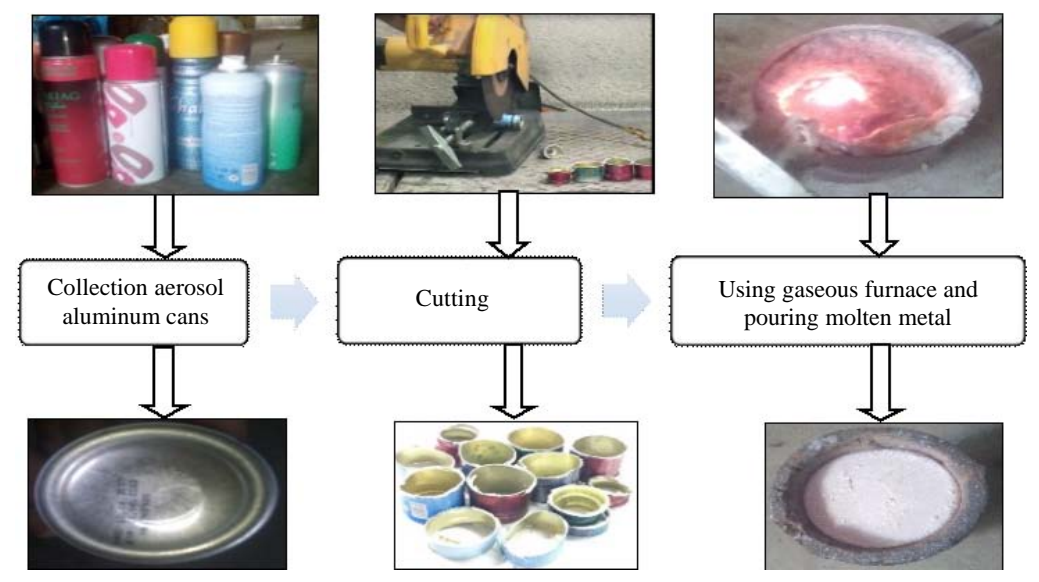

Fig. 1: Stages of recycling aerosol aluminum cans

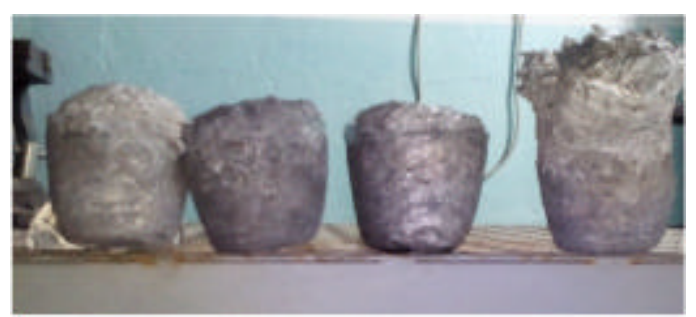

Fig. 2: Foam castings produced
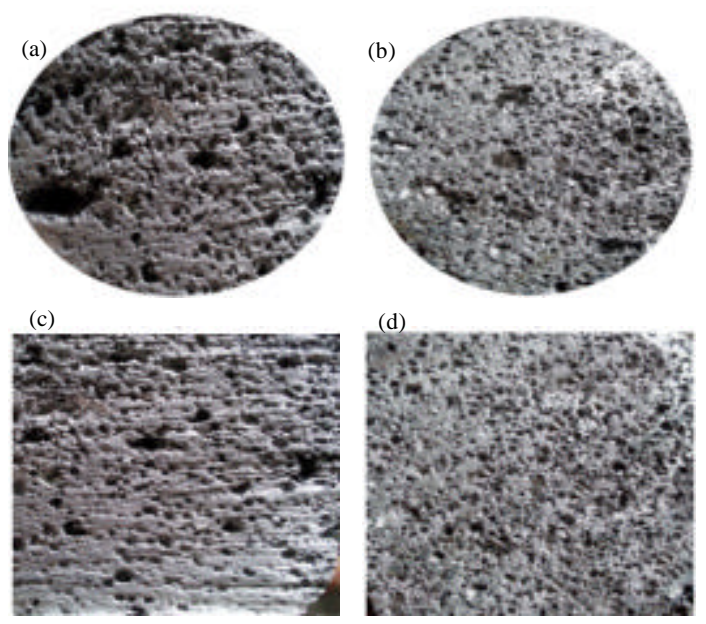

Fig. 3: Foams resulted using different grain size of dolomite: a) $90 \mu \mathrm{m}$, b) $125 \mu \mathrm{m}$, c) $150 \mu \mathrm{m}$ and d) $180 \mu \mathrm{m}$

The required quantity of recycled aerosol aluminum cans was weighted and placed in a graphite crucible $(2 \mathrm{~kg}$ capacity) and melted by using an electric resistance furnace. A thermocouple used to measure molten metal temperature. At temperature reached about $675^{\circ} \mathrm{C}$ for the molten metal, a stainless steel stirrer for about $(40-50 \mathrm{sec})$ was used to stir the melt, after that the furnace was switched off. Then the milled dolomite rocks which sieved to $(90,125,150,180 \mu \mathrm{m}$ (added into the molten metal while stirring. The stirring of $(1.5 \mathrm{wt} \%)$ for $\mathrm{CaMg}\left(\mathrm{CO}_{3}\right)_{2}$ was continued until obtaining a uniform distribution of foaming agent. Then the furnace switched on again and sited at $650^{\circ} \mathrm{C}$. About $13 \mathrm{~min}$ in the furnace was the holding time of foams to complete decomposition of foaming agent. Then the crucible was moved out from the furnace. By using jet of the air the foams were cooled. Finally, the foams resulted was removed from the crucible as shown in Fig. 2 and cut to make tests shown in Fig. 3.

\section{RESULTS AND DISCUSSION}

The samples of foam resulted were examined for a number of pores per inch. Pores per inch along vertical and the horizontal direction were measured by using Image J Software (V. 1.52). Also, the density of the aluminum foam, relative density (i.e., foam density divided to solid density), the energy absorbed and porosity level was calculated. The difference of pores per inch and energy absorbed with grain size is depicted in Fig .4a and $b$, respectively. Pores per inch, foam density, relative density, porosity level of the foams produced with different grain sizes of $\mathrm{CaMg}\left(\mathrm{CO}_{3}\right)_{2}$ are presented in Table 2 . 
Table 2: Physical properties of fabricated foams

\begin{tabular}{llllll}
\hline $\begin{array}{l}\mathrm{CaMg}\left(\mathrm{CO}_{3}\right)_{2} \\
\text { Grain size }\end{array}$ & $\begin{array}{l}\text { Pores } \\
\text { per inch }\end{array}$ & $\begin{array}{l}\text { Density of } \\
\text { foam }\left(\mathrm{g} / \mathrm{cm}^{3}\right)\end{array}$ & $\begin{array}{l}\text { Relative } \\
\text { density }\end{array}$ & $\begin{array}{l}\text { Level of } \\
\text { porosity }(\%)\end{array}$ & $\begin{array}{l}\text { Energy } \\
\text { absorbed } \\
{\left[\mathrm{MJ} / \mathrm{m}^{3}\right]}\end{array}$ \\
\hline 50 & 23 & 0.89 & 0.33 & 67.55 & 0.5 \\
125 & 19 & 0.71 & 0.27 & 73.12 & 0.47 \\
150 & 17 & 0.68 & 0.25 & 75.31 & 0.45 \\
180 & 13 & 0.59 & 0.21 & 79.21 & 0.42 \\
\hline
\end{tabular}
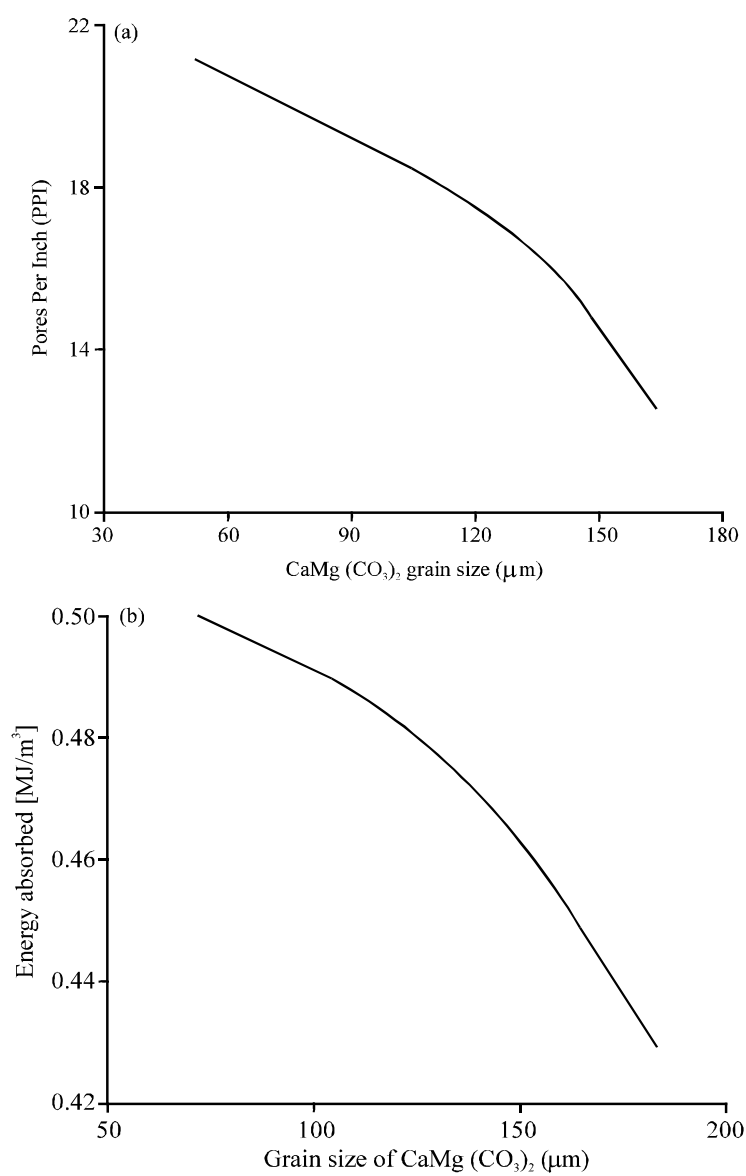

Fig. 4: Plot of effect grain size of $\mathrm{CaCO}_{3}$ on: a) number of pores per inch and b) energy absorption of resulted foams

\section{CONCLUSION}

Successfully aluminum foam alloy with closed cells was produced using dolomite as a foaming agent with different grain sizes and aerosol aluminum cans as raw material. It is noted that as the grain size of $\mathrm{CaMg}\left(\mathrm{CO}_{3}\right)_{2}$ decreases, the number of pores per inch, energy absorption, density of foams and relative density increases. While porosity level increases as the grain size of $\mathrm{CaMg}\left(\mathrm{CO}_{3}\right)_{2}$ increases. On the other hand despite of the uniform structure sample foam which fabricated with $180 \mu \mathrm{m}$ of grain size but in comparison with other production methods like Cymat, Alulight and Alporas process, the relative density of the foam produced is higher, this due to the effect of viscosity moldier in Cymat, Alulight and Alporas foams is better than the moldier of viscosity resulted by dolomite in control properties of metal foam (Koehler et al., 2000). However, using dolomite as a foaming agent and aerosol aluminum cans in present research introduced cheap aluminum foams with a uniform structure.

\section{REFERENCES}

Ashby, M.F., T. Evans, N.A. Fleck, J.W. Hutchinson and H.N.G. Wadley et al., 2000. Metal foams: a design guide. Elsevier, Amsterdam, Netherlands, ISBN:9780080511467, Pages: 251.

Curran, D.C., 2004. Aluminium foam production using calcium carbonate as a foaming agent. Ph.D Thesis, University of Cambridge, Cambridge, England.

Koehler, S.A., S. Hilgenfeldt and H.A. Stone, 2000. A generalized view of foam drainage: Experiment and theory. Langmuir, 16: 6327-6341.

Krewski, D., R.A. Yokel, E. Nieboer, D. Borchelt and J. Cohen et al., 2007. Human health risk assessment for aluminium, aluminium oxide and aluminium hydroxide. J. Toxicol. Environ. Health Part, 10: 269-269.

Miyoshi, T., M. Itoh, S. Akiyama and A. Kitahara, 1998. Aluminum foam, ALPORAS: The production process, properties and applications. MRS. Online Proc. Lib. Arch., 521: 125-132.

Papadopoulos, D.P., H. Omar, F. Stergioudi, S.A. Tsipas and N. Michailidis, 2011. The use of dolomite as foaming agent and its effect on the microstructure of aluminium metal foams-comparison to titanium hydride. Colloids Surf. Physicochem. Eng. Aspects, 382: 118-123.

Song, Z.L., J.S. Zhu, L.Q. Ma and D.P. He, 2001. Evolution of foamed aluminum structure in foaming process. Mater. Sci. Eng.,q 298: 137-143.

Sorenson, J.R., I.R. Campbell, L.B. Tepper and R.D. Lingg, 1974. Aluminum in the environment and human health. Environ. Health Perspect., 8: 3-95.

Yang, D.H., B.Y. Hur, D.P. He and S.R. Yang, 2007. Effect of decomposition properties of titanium hydride on the foaming process and pore structures of $\mathrm{Al}$ alloy melt foam. Mater. Sci. Eng., 445: 415-426. 